Data banks

\section{Right to privacy}

Brussels

Following the adoption of the European Parliament's resolution on the rights of the individual with respect to data processing, it now seems that the European Commission may well start work on drafting legislation to protect the confidentiality of information held in data banks. The European Parliament's resolution at the plenary session in Strasbourg last month has particular relevance for the United Kingdom which has so far shied away from tackling the controversial issues of the freedom or protection of information.

Respect for the individual's privacy has become a matter for international organizations like the EEC and the Council of Europe because of the increasing amount of information which is passed across national borders for processing or storage. The fear is that countries without satisfactory legislation on the subject might become information "havens", analogous to offshore banking centres, remote from the judicial control of the country of origin. The lack of adequate laws in the United Kingdom has become a significant impediment to the growth of the UK data processing industry, causing Sweden not to send data to the United Kingdom for processing.

At the moment there are non-binding guidelines drawn up by the Organization for Economic Development and Cooperation (OECD), and a convention for the protection of individuals with regard to automated data files has been approved but not yet ratified by the Council of Europe. The convention sets out the basic principles of data protection. These include the fair and lawful collection of data, restrictions on the storing of particular data and prohibitions on the storing of sensitive data such as political opinions. The convention also gives anybody about whom data are held the right to obtain information about the nature of the data from the agency officially responsible and to demand that inaccurate data are corrected. What categories of data can be excluded from the scope of the convention and whether dataprotection rights are given to groups of people, associations or companies are left to the discretion of the signatory countries.

The OECD guidelines, which the United Kingdom, Canada and Australia have objected to, are more in line with the views of the United States, particularly the insistence that data should flow across borders unhindered by administrative checks or delays.

Neither of these international codes is yet in operation although many European countries have well established laws on information and data control. The European Parliament's rapportcur, Hellmut Sieglerschmidt (German, Socialist),

\title{
Fishy proof
}

This painted goby, the onehundredth species of fish to be found in the River Thames, has been greeted by Thames Water's chairman Geoffrey Edwards as proof that the Thames is the cleanest metropolitan estuary in the world. This follows the "cleanup" campaign of London's sewage system that began in 1960 .

concluded that the different national rules are damaging for both the individual and for the data processing industry. In his view, the convention proposed by the Council of Europe leaves too many aspects to the discretion of signatory states. Sieglerschmidt called for a more radical EEC directive. Ideas in this proposal include: the same level of protection in both private and public sectors; the obligation for data holders to notify persons on whom information is held and permit corrections to be made; and the right of the subject of the data to claim for damages against data holders. These proposals were toned down by amendments from Conservatives. Jasper Becker

\section{Science parks}

\section{Easy answer?}

With cuts in government support hitting UK universities hard, the scramble to set up science parks is on -15 were launched last year. Few university schemes are actually in operation, and newcomers must look to Trinity College, Cambridge, the first British academic institution to open a science park, for the blueprint.

"Science park" is a vogue term applied to many different schemes. Local authority backed projects, such as that in Warrington, aim to attract high technology industry in the hope of creating more jobs. The universities hope that science parks will earn extra income and provide an environment in which academic scientists and entrepreneurs can put new technology onto the market.

In 1973 Trinity earmarked 140 acres on the outskirts of the town for development. Phase 1 is now complete and the site houses 23 companies. When Napp Laboratories Lid, a pharmaceutical company, moves into the new building it is constructing, the number of people working on the site will total 1,000. Trinity is well pleased with its park, collecting around $£ 250,000$ a year from lease arrangements, and content at having no equity shares in any of the companies. No companies have moved out and several have expanded their premises. "Every major univers:ty should have onc", commented John Bradficld, bursar of Trinity.

The park's tenants range from small companics founded by one or two business-minded science graduates to divisions of multinational companies. LKB Biochrom Ltd, the British subsidiary of a Swedish firm, was attracted to the park because of its proximity to a prestigious university. LKB moved to the park in 1974 and produces analytical instruments used in life science laboratories. According to $\mathrm{Mr}$ David Storey, LKB's managing director, the attitude of academic researchers to commerce has undergone "a remarkable change over the past ten years". Many members of the university now act as consultants on either an informal or formal basis, in sharp contrast with the hostility met by IBM twenty years ago when it tried to find premises in Cambridge.

Laser-Scan Laboratories Ltd, which came to the park in 1973, grew directly out of a university department. Founded in 1969 by three researchers from the Cavendish Physics Laboratory, LaserScan produces machines, used by the Ordnance Survey and the Ministry of Defence, based on laser scanning technology. Products made by the university engineering department's Microcircuits Group, which is supported by GEC, British Telecom and the Science and Engineering Research Council, will be marketed by a company on the park, Lintech Instruments. Although the park has demonstrated, as one research worker put it, that academics need not "wholly prostitute themselves to become entrepreneurs", it is not yet looked on as part of the university. Its distance from the university prohibits such an intimate involvement.

Cambridge Science Park is an example of a scheme established in response to government pleas in the late 1960 s that industry and the universities form closer links. In 1969 a Cambridge committee chaired by Sir Nevill Mott recommended expansion of science-based industry close to the university. Dr Bradfield, who has guided the scheme from its inception, sees science parks as a means of educating academics in the commercial development of their ideas. The Cambridge Science Park has, in this respect, proved successful. But to look to science parks for a significant boost for British high technology, or as a way for universities to replace lost income, is optimistic. High technology companies are notoriously high risk ventures and present conditions are not conducive to overnight success.

Jane Wynn 